\title{
8 \\ The New Pacific Diplomacy at the United Nations: The rise of the PSIDS ${ }^{1}$
}

\section{Fulori Manoa}

Since 2009 there has been a marked elevation in the profile of the Pacific Island countries at the United Nations (UN). Nauru's much publicised chairmanship of the Alliance of Small Island States (AOSIS), Fiji's successful chairmanship of the G77 plus China in 2013, and Samoa's hosting of the Third International Conference of Small Island Developing States are the more telling signs of this rise in prominence. In addition, Pacific Island countries are now making it onto important UN committees and taking up leadership roles. Much of this new recognition at the UN can be attributed to the Pacific Island countries organising and working together as Pacific Small Island Developing States (PSIDS). This paper seeks to briefly tell the story of the PSIDS, who they are, why they organise the way they do, and outline some of the successes that they have achieved.

\footnotetext{
1 In June/July of 2014, I was privileged to be able to interview eight Pacific Island Ambassadors to the United Nations, 12 Pacific diplomats, and two advisers. I was able to speak to officials from 11 out of the 12 Pacific Island missions. I am exceedingly grateful to the ambassadors, diplomats and advisers for their time and help in sharing with me the story of the Pacific Small Island Developing States at the United Nations.
} 
The PSIDS comprises 14 Pacific Island countries: Cook Islands, Federated States of Micronesia, Fiji, Kiribati, Nauru, Niue, Palau, Papua New Guinea, Marshall Islands, Samoa, Solomon Islands, Tonga, Tuvalu, and Vanuatu. When discussing the PSIDS in the context of the UN, the Cook Islands and Niue are not included, as they are not UN members; however, their names appear on official PSIDS stationery, their flags are included in the logo, and they are able to be part of group statements. For the purpose of this paper, PSIDS refers to the PSIDS who are members of the UN - the UN PSIDS.

When the idea of forming a PSIDS grouping first materialised, it was envisioned as a collective of the Pacific Island Forum (PIF) countries minus Australia and New Zealand. It initially grew out of a need to raise funds for projects around climate change adaptation and mitigation, renewable energy and pollution, but the structure proved successful and it has been consolidated over the past five years to the point where it has become arguably the most important part of the way in which Pacific Island countries engage at the UN.

The PSIDS is a New York-based, United Nations-specific grouping. This is highlighted by the case of Kiribati. Kiribati joined the UN in 1999, but it was not until September of 2013 that it established a mission in New York. A survey of PSIDS statements to a variety of different forums clearly shows that before the establishment of the Kiribati Permanent Mission, only rarely would Kiribati be included in a PSIDS statement. It was only after September 2013 that it became a 'regular' on the list of countries included in the PSIDS statements.

The PSIDS is founded on consensus; members circulate, make joint statements, and agree on which issues to pursue together. Although they have common interests and are recognised as a cohesive grouping, lobbied by other countries, they are not a voting bloc and pursue their national interests individually.

\section{From the Forum Group to the PSIDS}

According to Powles (2002, p. 72), writing more than a decade ago, the Pacific states at that time were organised into a Pacific Group which met once a month, made joint statements, and cooperated closely. The Pacific Group comprised members of the PIF that were also members of the UN. In other words, the Pacific Group comprised Pacific Island countries and Australia and New Zealand. The forum group ambassadors continue to meet, and they do release joint statements from time to time. However, today, the PSIDS is the primary vehicle for advocacy at the UN among Pacific Island countries. A long-serving ambassador put it this way: 'the Forum group still meets but not as regularly as it used to and it does not deliver as many joint statements as it used to. PSIDS, 
as a group, are making more statements' (personal communication 10 July 2014). The PSIDS ambassadors officially meet once a month, or more often if necessity dictates - if there are important ongoing negotiations, for example. They are also in regular electronic contact.

PSIDS meetings do not only take place at the ambassadorial level, which is an improvement on the meeting model that exists in the forum group. The PSIDS has also incorporated a working group, made up of staff from all the missions. A task of this working group is to examine the current issues at the UN, draft the PSIDS positions and make recommendations to the ambassadors for their approval.

\section{Why the Shift from PIF to PSIDS?}

There are a number of reasons why PSIDS gained impetus and superseded the PIF as the main body for Pacific Island country organising at the UN, including: differing interests with Australia and New Zealand, necessity, logic, and Fiji's suspension from the PIF.

\section{Differing Interests}

Powles (2002, p. 71) highlights the marginalisation experienced by the Pacific countries as a reason for their finding other avenues to make themselves heard. At that time, that meant organising through the forum group, however, it would seem that the Pacific Island countries and their issues were marginalised within the forum group. Joining their voices to those of Australia and New Zealand undoubtedly made their voices louder but, in practice, this actually muzzled them on issues where their interests diverged from those of their metropolitan forum colleagues. This was a point that most of the ambassadors and diplomats agreed upon. There was the general feeling that, since Australia and New Zealand were donor countries, they dealt with issues in different ways to the rest of the members of the forum group. Some were even of the view that Australia and New Zealand were using the forum group to promote their own interests, and that these interests clashed with the rest of the forum group on important issues such as climate change. For Pacific Island countries, sustainable development and climate change are the most important issues at the UN. To be marginalised within your own grouping on these issues would be grounds to find another avenue by which to make your voice heard. As one diplomat said: 
PSIDS issues were never at the centre, the agenda was dictated by those that held the purse strings. If the issues were at all addressed, they were addressed sub-standardly. Within the region, the same actors and institutions are still at play, so why not form a different entity in New York at the UN to address the real challenges of the PSIDS (personal communication 2014).

\section{Necessity}

The average Pacific Island mission to the UN has three diplomats, including the ambassador, as compared to 33 diplomats at the Australian mission, and 14 diplomats at the New Zealand Mission. These numbers may seem ample for a Pacific high commission or embassy in another country, but for the sheer volume of work at the UN, these numbers can be woefully inadequate. Apart from the work of running the mission, which can range from consular and legal work to administration and finances, diplomats also have to deal with the plethora of issues and meetings that take place every day.

The United Nations General Assembly has six main committees and meetings for these committees run simultaneously. With the average of three staff per mission (in many cases less) it would be impossible for one PSIDS mission to cover all these meetings, or even all the relevant meetings. Every ambassador and diplomat spoke about the enormity of the work load and the importance of being strategic and working together. PSIDS ambassadors and other diplomats rely upon one another to cover meetings that they cannot attend and, in doing so, safeguard each other's interests. Not only do they share notes, there is genuine warmth within the grouping, and it is not unusual to have diplomatic staff from one mission calling another mission to ask for help with meeting timetables and venues or procedure.

Over the years, not much has changed in terms of manpower for the Pacific Island country missions. But recently a lot more has been achieved. Much of this can be ascribed to the collective work that is taking place amongst the PSIDS missions in New York.

Powles (2002, pp. 74-75) also talked about regional group membership as a 'daunting challenge' for the Pacific Forum Group at the United Nations, due to New Zealand and Australia being members of the Western European and Others group, and the Pacific Islands being members of the Asian group. At that time, Australia and New Zealand were pushing to bring the region together in its own UN-recognised grouping, to boost the status and influence of the region. Since then, however, the UN has reconfigured that particular status quo so that the Pacific Islands countries are part of the PSIDS group within the renamed Asia Pacific group (Tarte 2013, p. 2). It is through these groups that much of 
the work at the UN is done - voting, for example. It makes more sense for the Pacific Island countries to work together to raise their profile and push their interests within their own grouping.

\section{Fiji's Suspension from the Pacific Island Forum}

A few ambassadors place Fiji's suspension from the PIF in 2009 as central to the formation of, or the impetus given to the PSIDS. It was felt that Fiji's suspension lead to the reconfigured grouping as it became a necessity to ensure that Fiji was not left out after its suspension from the PIF. PSIDS was the space in which other Pacific Island countries could continue to engage with Fiji and thus the importance of the PSIDS grouping grew. The PSIDS grouping was subsequently found to be a 'comfort zone' for the Pacific Island countries, as they shared similar interests. Once they started meeting and engaging as PSIDS, recognition of the PSIDS as a separate entity from the PIF followed.

At the time Fiji was suspended from the PIF, PSIDS was already in existence and there were joint statements and actions already taking place. However, after Fiji's suspension PSIDS members began to act more in concert. This is measured by the amount of PSIDS statements that have been made and the achievements of the PSIDS at the United Nations. This gives support to the argument that Fiji's suspension from the forum was a catalyst to the PSIDS' subsequent rise at the UN. In this case, Fiji's departure from democracy can be said to have actually been a positive factor for the PSIDS in the pursuit of their goals at the UN and other global forums.

\section{Has Organising as the PSIDS Yielded Success? How has it done this?}

Success is a relative term, and it means different things in different situations. In order to get a truer picture of PSIDS' success at the UN, it is necessary to first examine what success means for the PSIDS and for individual PSIDS representatives to the UN. The underpinning definition of success for the ambassadors and diplomats was to have the ability to effect positive change for the people back in their home countries, through their work and advocacy at the UN. There also existed the notion of success as recognition, that is, being able to draw and maintain attention at the international forum despite myriad competing demands and differences. Taking into account these two main criteria - being able to effect change, and being recognised - it would not be amiss to say that the PSIDS have met with considerable success at the UN. This success has not come without serious effort; there were a series of strategic actions that the PSIDS undertook to achieve the success they are enjoying now. 
In 2010, the PSIDS representatives met and decided on a plan of action to raise their profiles at the UN. The first course of action was to change the name of the Asian Group ${ }^{2}$ to the Asia-Pacific Group. This was important to the PSIDS because they believed that how they were perceived carried a great deal of weight and to be able to achieve their ends they needed the recognition that a name change would bring. They were told that it would be impossible, but 14 months later they were able to achieve the name change. Officially, the group is now called the Group of Asia and the Pacific Small Island Developing States (Radio New Zealand 2011), however, the shortened form, the Asia-Pacific group, is in more frequent use. Achieving this level of acknowledgement made it easier and more plausible for the Pacific Island countries to put forth the PSIDS as the proper grouping to address the issues of the Pacific Island countries. This links directly to the change in focus from the PIF group to the PSIDS.

The PSIDS then started to assert themselves, insisting that the PSIDS and not the forum was the right grouping to address the issues that related to Pacific Island nations. The recognition of their group implied in the name change of the voting bloc was reflected in the PSIDS taking up the rotating monthly chair of the Asia-Pacific group when it was their turn. This laid the foundation for the next push, which entailed strategically tackling the candidature charts for elections within the UN. Changing the name of the Asian Group to the AsiaPacific Group and becoming more involved in the running of that group was integral to the success of the PSIDS venture into the candidature charts, because the selection of candidates for elections is done through the regional grouping. The PSIDS coordinate amongst themselves and decide who should take up the seats that they find relevant to their advocacy.

A look at the Asia-Pacific Group's candidature charts for September of 2014 revealed PSIDS countries in key positions directly relevant to their development issues. Fiji sits on the United Nations Commission on International Trade (UNCITRAL) and the Governing Council of United Nations Environment Programme (UNEP). It also sits on the Executive Board of the United Nations Development Programme (UNDP), the United Nations Population Fund (UNFPA), and the United Nations Office for Project Services (UNOPS), and is currently chairing the bureau of the executive board. Fiji and Tonga are members of the Council of the International Seabed Authority. Papua New Guinea currently sits on the Executive Board of the United Nations Children's Fund (UNICEF) and the Executive Board of the United Nations Educational, Scientific and Cultural Organization (UNESCO). Solomon Islands currently sits on the Executive Board of United Nations Women and the Bureau of that executive board. Samoa currently

2 The Asian Group is one of the regional groupings at the United Nations, the others being the African Group, Eastern European Group, Latin American and Caribbean Group, and the Western European and Other Groups. 
has an expert in the Committee on the Rights of the Child (CRC). Some of these PSIDS are serving the last leg of their tenure of these seats, but in some cases other PSIDS have been lined up to receive seats on the same boards, so that PSIDS interests are looked after. For example, Fiji's term on the Executive Board of UNDP/UNFPA/UNOPS ends in 2015 but the PSIDS have endorsed Samoa to take up a seat on that board once Fiji's term is up.

Also significant is the position of Vice President of the United Nations General Assembly (UNGA). At every UNGA, 21 vice presidents are elected and among their tasks is to sit on the general committee that scrutinises the provisional agenda at the start of the UNGA session (UNGA 2014). Since 2011 (66th session), the PSIDS have had one of their number as Vice President of the UNGA, with Kiribati currently a vice president (69th session), and Fiji taking over for the 70th session. While PSIDS countries have had vice presidency of the UNGA before (starting with Fiji in 1973: 28th session), never has there been this level of sustained representation and, consequently, recognition.

With recognition comes more leverage, and this has been the case with the PSIDS and their advocacy. Examples of this success in recent years include the passing of the first climate change resolution, French Polynesia's reinscription onto the list of non-self-governing territories and achieving stand-alone Sustainable Development Goals (SDGs) on oceans and climate change. These examples are discussed below.

On 3 June 2009, the UNGA unanimously adopted a resolution titled 'Climate Change and its possible security implications'. A few longer-serving diplomats flagged this as an important early achievement for the PSIDS, as they had to campaign hard for a long time to see it come through. This was recognised by Australia's representative at the time, who said, after the resolution was adopted, that it demonstrated regard for some of the smaller states in the international arena and that those states deserved congratulations for their dignified participation in the long negotiations'. If United States government cables revealed by WikiLeaks are anything to go by, it would seem that the PSIDS did make an impact. One document clearly outlines that the United States had intended that the option of negotiating the resolution was only to be used as a 'fall back'. ${ }^{3}$ The resolution is not as strong as it could be, but the fact that it was adopted and the PSIDS were able to force the hand of the United States to adopt the fall-back position can be seen as a victory.

The second illustration of success illustrates the prominence of the Pacific Island countries at the United Nations. On 17 May 2013, French Polynesia was reinscribed onto the UN list of non-self-governing territories by a UNGA

See wikileaks.org/plusd/cables/08STATE82276_a.html. 
resolution that was sponsored by Solomon Islands, Nauru, and Tuvalu with support from Vanuatu, Samoa, and Timor-Leste (Maclellan 2013). The Pacific Islands (acting as the forum) have had prior success getting a territory on the list. In 1978, Papua New Guinea, Solomon Islands, Fiji, and Western Samoa (now Samoa) launched a collective attack on France's continuing colonial presence in the South Pacific at the UNGA. For the next ten years, New Caledonia was a main topic at forum meetings (Fry 1994, p. 167). Between 1980 and 1986, there was a split in the forum on what to do about New Caledonia, as some countries wanted to play it safe with France and not embarrass a world power (Fry 1994, p. 167). However a centre-right change in government in that metropolitan country put the island leaders, along with Australia and New Zealand, on the same team. Vanuatu requested and gained the Non-Aligned Movement's support at the UN and the resolution for reinscription was passed, 89 votes to 24 (Fry 1994, p. 168). It is important to note here that the Pacific Island countries had to get Australia and New Zealand on side before they were able to achieve their ends.

By stark contrast, with the reinscription of French Polynesia, Australia was not supportive of the action (Maclellan 2013). Thus collective Pacific action did not come through the forum. At the forum meeting in August 2012, the call for reinscription was not endorsed, but one month later at the UN, leaders from Samoa, Solomon Islands, Fiji, and Vanuatu made the call for decolonisation at the UN and the following year in February the ambassadors for Solomon Islands, Tuvalu, and Nauru formally lodged a draft resolution at the UN which was adopted, despite strong French opposition (Maclellan 2013).

Aside from the success of helping French Polynesia work toward self-determination, for the PSIDS this represented a success in achieving autonomy from Australia and New Zealand. A long-time diplomat at the UN said that in the past (when the Pacific Islands Forum was still the main Pacific Island grouping), when the Pacific Islands wanted something, they would ask Australia and New Zealand for help, and they relied heavily on them in this way. Now, however, they meet up as PSIDS and discuss their issues and the things that they want to advocate before they inform Australia and New Zealand, and they do not depend solely on their support.

What may be the PSIDS's most important success in advocacy to date is the negotiation of climate change and oceans as stand-alone sustainable development goals. These goals will feed into the post-2015 development agenda. Virtually every ambassador and diplomat interviewed spoke at length about the importance of having these goals included and a few also talked about the renewable energy goal. There were other issues that were also important, but oceans and climate change needed to be championed in order for them to be included. There were 30 seats in the open working group for the sustainable 
development goals, seven of which were allocated to the Asia-Pacific Group. The PSIDS were represented by a troika of Nauru, Palau, and Papua New Guinea, who shared a seat (Sustainable Development Knowledge Platform 2014). PSIDS diplomats who were involved in the negotiation of the sustainable development goals talked about the difficulty involved in trying to negotiate comprehensive stand-alone goals for oceans and climate change. However, on 12 August 2014, the report of the Open Working Group of the General Assembly on Sustainable Development Goals was submitted to the UNGA, Amongst the 17 goals were 'Take urgent action to combat Climate Change and its effects' and 'Conserve and sustainably use the oceans, seas and marine resources for sustainable development' (UNGA 2014). It is recognised that the Pacific countries were very active in their SDGs campaign. In his address to the Pacific Islands Forum (the PSIDS is not an official grouping while the PIF is recognised) leaders on 26 September in New York, the UN Secretary General commended them on their advocacy of the stand-alone goal on oceans.

It has been over 40 years since the first Pacific Island country joined the UN; now the Pacific Islands have reached a stage where they are able to assert themselves and influence decisions in this global forum. In 2004, Pacific Island ambassadors were feeling very marginalised at the UN and they felt that their issues were not getting the attention they deserved (McNamara 2009). Ten years later, Pacific Island ambassadors and other diplomats are a lot more positive about their role at the UN. They have made great gains at the world body. Much of this can be attributed to the new Pacific diplomacy at the UN - working together and working innovatively. Pacific collective diplomacy is arguably strongest at the UN in New York, and this is fostered by shared interests, the need to work together, distance from the region, and proximity to each other in New York. The PSIDS model of cooperation is testament to the fact that 'smallness' and a lack of resources does not have to translate into helplessness. The Pacific Islands, acting together as PSIDS, have met with success at the UN, but according to one long-serving Pacific ambassador, 'success is a journey', and continued success will depend on whether or not advocacy can be continued at this level (personal communication 2014). This is the challenge for the PSIDS.

\section{References}

Fry, G., 1994, 'International Cooperation in the South Pacific: From Regional integration to collective diplomacy', in W. A. Axline (ed.), The Political Economy of Regional Cooperation: Comparative case studies, Pinter Publishers, London. 
Maclellan, N., 2013, 'Hijacking Decolonisation: French Polynesia at the United Nations', Inside Story. Available at: insidestory.org.au/hijackingdecolonisation-french-polynesia-at-the-united-nations.

McNamara, K.E., 2009, 'Voices from the Margins: Pacific ambassadors and the geopolitics of marginality at the United Nations', Asia Pacific Viewpoint 50(1), pp. 1-12.

Powles, M., 2002, 'Making Waves in the Big Lagoon: The influence of Pacific Island Forum countries in the United Nations', Revue Juridique Polynésienne 2, pp. 59-76.

Radio New Zealand, 2011, 'Asian Group of Nations at the UN Changes its Name to Asia-Pacific Group'. Available at: www.radionz.co.nz/international/ pacific-news/199302/asian-group-of-nations-at-un-changes-its-name-toasia-pacific-group.

Sustainable Development Knowledge Platform, 2014, 'Open Working Group on Sustainable Development Goals'. Available at: sustainabledevelopment. un.org/owg.html.

Tarte, S., 2013, 'A New Regional Pacific Voice?: An observer's perspective on the Pacific Islands Development Forum (PIDF), inaugural summit, Denarau, Fiji, 5-7 August 2013', Pacific Island Development Program, Honolulu. Available at: www.eastwestcenter.org/sites/default/files/private/pib004.pdf.

United Nations General Assembly (UNGA), 2014. Main Committees: General Committee. Available at: www.un.org/en/ga/general/general.shtml. 
This text is taken from The New Pacific Diplomacy, edited by Greg Fry and Sandra Tarte, published 2015 by ANU Press, The Australian National University, Canberra, Australia. 